\title{
Platelet $\alpha$-Granule Fibrinogen, Albumin, and Immunoglobulin G Are Not Synthesized by Rat and Mouse Megakaryocytes
}

\author{
Prem Handagama, * Daniel A. Rappolee, ${ }^{*}$ Zena Werb, ${ }^{\ddagger}$ Jack Levin,"11 and Dorothy F. Bainton* \\ ${ }^{*}$ Department of Pathology, ${ }^{\ddagger}$ Laboratory of Radiobiology and Environmental Health, and ${ }^{\S}$ Department of Laboratory Medicine, \\ University of California, San Francisco, California 94143; and "Veterans Administration Medical Center (113A), \\ San Francisco, California 94121
}

\begin{abstract}
It has been assumed that endogenous synthesis by the platelet precursor cell, the bone marrow megakaryocyte, is the major source of platelet $\alpha$-granule protein. To test this hypothesis, we used mRNA phenotyping to detect in megakaryocytes the presence of mRNA transcripts specific for various proteins. Our results indicate that megakaryocytes synthesize platelet factor 4 , a protein relatively specific for platelets, but do not express mRNA transcripts for the fibrinogen, albumin, or IgG found in $\alpha$-granules. We have previously shown that megakaryocytes endocytose circulating proteins, including fibrinogen, albumin, and IgG, and incorporate them into $\alpha$-granules. Thus, platelets appear to contain a unique type of secretory granule whose contents originate by both endogenous synthesis and endocytosis from plasma. Under basal conditions, the source of $\alpha$-granule fibrinogen is plasma. (J. Clin. Invest. 1990. 86:1364-1368). Key words: plasma proteins • PCR • mRNA phenotyping • secretory granule
\end{abstract}

\section{Introduction}

The function of many tissues and cells is delineated by the specific proteins they synthesize and secrete. The secretory granules of neutrophils and cells of the pancreas and the salivary gland have been studied extensively, and the biosynthetic route of their cell-specific proteins has been elucidated $(1,2)$. In these cell types, the proteins are endogenously synthesized and then packaged into granules. Platelets are anucleate cells that secrete the contents of their main storage organelles, the $\alpha$-granules, at sites of vascular injury. The secreted substances, together with coagulation proteins from plasma, contribute to the formation of a hemostatic plug. Platelets arise from bone marrow precursor cells called megakaryocytes. $\alpha$-Granule proteins such as fibrinogen and platelet factor 4 (PF-4), ${ }^{1}$ albu-

Address reprint requests to Prem Handagama, Dept. of Pathology, University of California, HSW-501, San Francisco, CA 94143-0506. 1990.

Received for publication 1 June 1990 and in revised form 13 July

1. Abbreviations used in this paper: PF-4, platelet factor 4; RT-PCR, reverse transcription-polymerase chain reaction.

J. Clin. Invest.

(c) The American Society for Clinical Investigation, Inc.

$0021-9738 / 90 / 10 / 1364 / 05 \quad \$ 2.00$

Volume 86, October 1990, 1364-1368 min, and IgG are immunohistochemically detectable in megakaryocytes $(3,4)$. Platelet fibrinogen, the predominant protein secreted from $\alpha$-granules, has been assumed to be synthesized by megakaryocytes. Reports have indicated that megakaryocyte-enriched marrow preparations synthesize fibrinogen $(5,6)$ and contain fibrinogen-specific mRNA (7). However, when IgG was localized to $\alpha$-granules, the hypothesis of endocytic origin of platelet granule proteins was presented (8). There is recent evidence to support this hypothesis. First, we and others have shown that when several proteins, including fibrinogen, albumin, and IgG, are administered intravenously, they are rapidly endocytosed by megakaryocytes and incorporated into $\alpha$-granules $(3,9-12)$. These proteins are later secreted by platelets after stimulation with thrombin. Second, when rats are maintained in a defibrinated state by injections of a snake venom enzyme (ancrod) that specifically degrades fibrinogen and removes it from the circulation, the megakaryocytes and platelets contain markedly reduced amounts of fibrinogen (13). Because the megakaryocyte, a cell with abundant rough endoplasmic reticulum, is thought to be the site where most platelet proteins are synthesized $(14,15)$, we undertook this study to determine whether megakaryoctes can synthesize these proteins.

\section{Methods}

Preparation of cellular RNA. Rat bone marrow megakaryocytes were enriched by a two-step process of density gradient centrifugation and velocity sedimentation as previously described (15), except that all procedures were carried out at $10^{\circ} \mathrm{C}$, and unit gravity sedimentation was used instead of centrifugation on a continuous Ficoll gradient. Bone marrow megakaryocytes $\left(2-5 \times 10^{4}\right)$ at $85 \%$ to $90 \%$ purity were processed by a microprocedure for RNA isolation that included adding $20 \mu \mathrm{g}$ of carrier Escherichia coli rRNA to each preparation $(16,17)$.

Mouse megakaryocyte colonies were grown in soft agar cultures as described previously (18-20). These colonies, composed entirely of megakaryocytes, developed in culture from megakaryocyte colonyforming cells ( $10-20$ cells per colony). Colonies (30-50 with a total of $\sim$ 500-800 megakaryocytes) were harvested directly into guanidine isothiocyanate solution containing $20 \mu \mathrm{g}$ of $E$. coli rRNA $(16,17)$, and whole RNA was purified.

$R N A$ phenotyping by reverse transcription-polymerase chain reaction (RT-PCR). RNA was reverse-transcribed with $100 \mathrm{U}$ of Moloney murine leukemia virus reverse transcriptase (Bethesda Research Laboratories, Gaithersburg, MD) as previously described $(16,17)$, except that $2 \mu \mathrm{g}$ of carrier $E$. coli rRNA was added to each reaction, and primed by random hexanucleotides or oligo(dT). One-tenth of the RT mixture was used in a PCR amplification primed by sequence-specific oligonucleotides (listed in Table I [21-26]) for 60 cycles, as described 
Table I. Design of Oligonucleotide Primers Used for RT-PCR

\begin{tabular}{|c|c|c|c|c|c|}
\hline Transcript & $\begin{array}{l}5 \text { 'Oligonucleotide (site } \\
\text { in sequence) }\end{array}$ & $\begin{array}{l}\text { 3'Oligonucleotide } \\
\text { (site in sequence) }\end{array}$ & $\begin{array}{c}\text { Fragment } \\
\text { length }\end{array}$ & $\begin{array}{l}\text { Diagnostic } \\
\text { restriction } \\
\text { enzyme }\end{array}$ & $\begin{array}{l}\text { Diagnostic } \\
\text { fragment } \\
\text { lengths }\end{array}$ \\
\hline & & & $b p$ & & $b p$ \\
\hline Albumin & $446-467$ & $1765-1743$ & 322 & Hinc II & $218+104$ \\
\hline$\alpha$-Fibrinogen & $5738-5764$ & $6766-6748$ & 373 & Apa I & $314+59$ \\
\hline$\beta$-Fibrinogen & $517-546$ & $699-673$ & 172 & Rsa I & $96+76$ \\
\hline$\gamma$-Fibrinogen & $1006-1030$ & $1247-1225$ & 241 & Taq I & $183+58$ \\
\hline PF-4 & $161-170,424-437$ & $744-723$ & 192 & Bam HI & $118+74$ \\
\hline$\beta$-actin & $25-48$ & $268-245$ & 243 & $\mathrm{Bgl} \mathrm{II}$ & $152+91$ \\
\hline $\operatorname{IgG}\left(\mathrm{C}_{\kappa}\right)$ & $2063-2086$ & $4803-4780$ & 223 & Hpa I & $135+88$ \\
\hline
\end{tabular}

Sequences are from published sources (21-26).

previously $(16,17) .8 \mu$ of the $50 \mu 1$ PCR mixture was electrophoresed in $4 \%$ agarose, and then stained with ethidium bromide as described $(16,17)$. Products of the RT-PCR were validated by predicted size, restriction enzyme analysis, or DNA bolt analysis.

Calculations. To calculate the minimum threshold number of mRNA transcripts per megakaryocyte, we first calculated the minimum threshold for detection of each mRNA species in the positivecontrol rat liver RNA. Each liver cell contains 100 pg of RNA (27), 3,000 transcripts of fibrinogen (28; Crabtree, G. R., personal communication), and 10,000 transcripts of albumin (Fausto, N., personal communication). We calculated the minimum threshold for number of transcripts by multiplying the number of transcripts in a liver cell by a ratio of the detection threshold for the species (in picograms, given in Table II) to the $100 \mathrm{pg}$ of total RNA in a liver cell (27). Thus, $(10,000$ transcripts of albumin mRNA per liver cell $) \times(1 \mathrm{pg}$ detection threshold for albumin $) \div(100 \mathrm{pg}$ RNA per liver cell) gives a minimum threshold of 100 transcripts of albumin.

The threshold for number of RNA transcripts in a single megakaryocyte from a colony was calculated by first multiplying the number of megakaryocytes harvested by the fraction of purified RNA recovered (determined from recovery of the carrier rRNA because this was in large excess of the megakaryocyte RNA) to give the number of megakaryocytes used in the $R T$ reaction. The number of megakaryocytes in each PCR reaction tube was determined by dividing the number of megakaryocytes in the RT reaction by the number of PCR tubes into which the RT mix was aliquoted. The threshold of a given mRNA species in the liver was then divided by the number of megakaryocytes in each PCR tube. In a typical experiment, RNA from 1,200 colony megakaryocytes was recovered at $66 \%$ yield and then analyzed in four PCR reaction tubes, giving 200 megakaryocytes in each PCR tube. With a detection threshold of 100 albumin transcripts for 200 megakaryocytes, 0.5 transcripts (or less) per colony megakaryocyte would be detected.

The threshold for number of mRNA transcripts in a single megakaryocyte in a megakaryocyte-enriched bone marrow preparation was determined by multiplying the total number of bone marrow cells by the percentage that were megakaryocytes and multiplying that number by the percentage of RNA recovered. This yielded the number of megakaryocytes per RT reaction. This number was divided by the number of PCR tubes per RT reaction to yield the number of megakaryocytes per PCR tube. The detection threshold for a given mRNA species in liver was then divided by the number of megakaryocytes in each PCR tube. In a typical experiment, RNA from 50,000 bone marrow cells consisting of $90 \%$ megakaryocytes was recovered at a yield of $66 \%$. If one-tenth of the RNA was analyzed in each PCR tube, then each reaction contained $\sim 3,000$ megakaryocytes. For albumin, 0.03 transcripts (or less) per bone marrow megakaryocyte would be detected.

Table II. Summary of mRNA Transcripts Expressed in Bone Marrow and Megakaryocytes (mk)

\begin{tabular}{|c|c|c|c|c|c|c|c|}
\hline \multirow[b]{2}{*}{ Transcript } & \multicolumn{3}{|c|}{ Presence of transcript } & \multirow[b]{2}{*}{$\begin{array}{l}\text { Detection threshold } \\
\text { of species in positive } \\
\text { control RNA }\end{array}$} & \multicolumn{3}{|c|}{ Calculated threshold for No. of mRNA transcripts } \\
\hline & $\begin{array}{l}\text { Whole } \\
\text { marrow }\end{array}$ & $\begin{array}{c}\text { Enriched } \\
\text { mk }\end{array}$ & $\begin{array}{l}\text { Pure mk } \\
\text { colonies }\end{array}$ & & $\begin{array}{l}\text { Positive } \\
\text { control } \\
\text { RNA }\end{array}$ & $\begin{array}{c}\text { Enriched } \\
\text { mk }\end{array}$ & $\begin{array}{l}\text { Pure mk } \\
\text { colonies }\end{array}$ \\
\hline & & & & $p g$ & & & \\
\hline \multicolumn{8}{|l|}{ Fibrinogen } \\
\hline$\alpha$ & $+(2)$ & $-(5)$ & $-(3)$ & 100 & 3000 & $<1.0$ & $\leq 15$ \\
\hline$\beta$ & $+(1)$ & $-(3)$ & $-(3)$ & 100 & 3000 & $<1.0$ & $\leq 15$ \\
\hline$\gamma$ & $+(2)$ & $\pm(4)^{*}$ & $-(3)$ & 10 & 300 & $<0.01$ & $\leq 1.5$ \\
\hline Albumin & $-(2)$ & $-(4)$ & $-(1)$ & 1 & 100 & $<0.03$ & $\leq 0.5$ \\
\hline $\operatorname{IgG}\left(C_{k}\right)$ & $+(1)$ & $\pm(1)^{*}$ & $-(1)$ & 1 & NC & NC & NC \\
\hline PF-4 & $+(2)$ & $+(4)$ & $+(3)$ & 100 & NC & NC & NC \\
\hline
\end{tabular}

Samples that were positive for the specific mRNA transcripts by RT-PCR are indicated by "+", those that were negative by "-", and those that were variable by " \pm ". The number of experiments, each performed with two or three replicate RNA preparations, is shown in parentheses. Detection thresholds were determined with whole liver RNA, except for $C_{\kappa}$, which was determined with mouse spleen RNA. The minimum thresholds for number of mRNA transcripts in positive control RNA and megakaryocytes were derived by calculation (see Methods). NC, not calculated. * One positive result was obtained with a preparation that had only $\sim 50 \%$ megakaryocytes. 

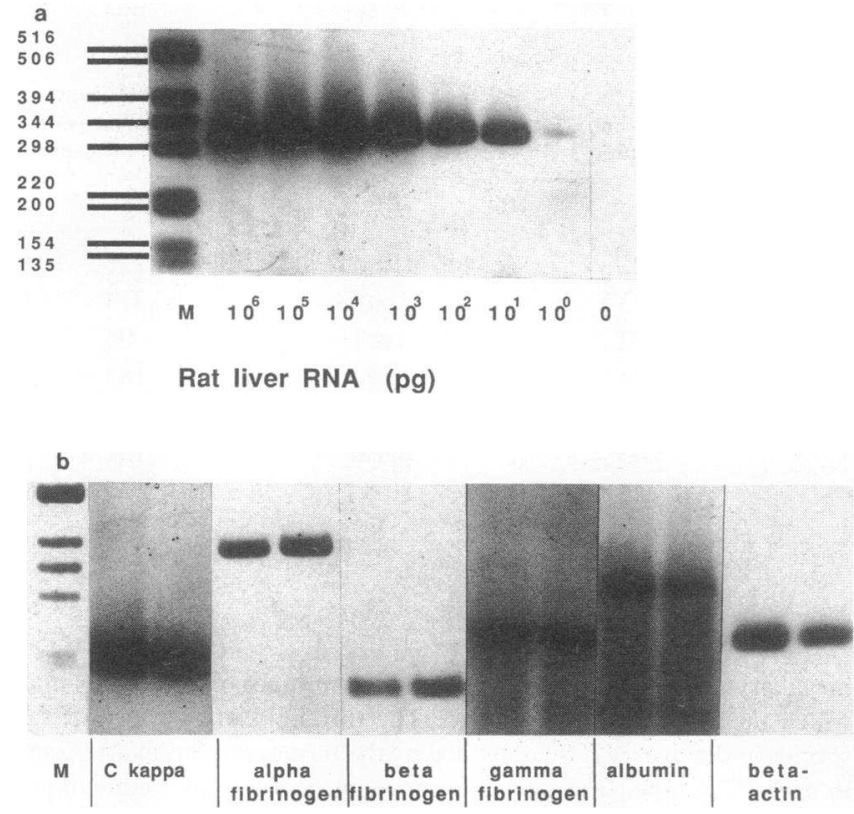

Figure 1. Expression of mRNA for $\alpha, \beta$, or $\gamma$ fibrinogen, albumin, or IgG in various cell types. (a) Example of the determination of the detection threshold of a species (albumin) in a dilution series of 10-fold positive control (whole rat liver) RNA processed by RT-PCR for 60 cycles. The thresholds of all RT-PCR reactions are given in Table II. The amount of RNA in each PCR reaction is indicated on the abscissa (in pg); $M$ is the ladder of molecular weight markers (Bethesda Research Labs) (in bp). (b) Test of oligonucleotide primers by RTPCR for sources of each specific mRNA. Whole RNA from duplicate samples of $100 \mathrm{ng}$ of rat liver (source of $\alpha, \beta, \gamma$ fibrinogen, albumin, and $\beta$-actin) or mouse spleen (source of $C_{\kappa}$ ) was reverse-transcribed, primed by oligonucleotides, amplified by 60 cycles of PCR, and then analyzed by electrophoresis in $4 \%$ agarose gels, followed by staining with ethidium bromide. Duplicate preparations are shown for each primer pair. All photographs are presented as negative images.

\section{Results and Discussion}

We used the method of mRNA phenotyping to detect mRNA transcripts for specific proteins in small numbers of cells. Megakaryocyte RNA was obtained from three types of cell preparations: $(a)$ whole rat bone marrow, in which $\sim 0.16 \%$ of the cells are megakaryocytes, $(b)$ megakaryocyte-enriched rat bone marrow, in which $85 \%-90 \%$ of the cells are largely stage II and III megakaryocytes (29), and (c) mouse megakaryocyte colonies grown in vitro for seven days. The latter two preparations correspond to the stage at which fibrinogen is known to appear in megakaryocytes (30). RNA from immature megakaryocytes, present in megakaryocyte colonies after three or five days of culture, was also analyzed. The colonies obtained from cultures served as the source of completely pure megakaryocytes, free of contamination by other cell types. Samples of mouse and rat liver, spleen, and macrophage RNA were purified and used as positive controls.

RT-PCR was sensitive enough to detect albumin (Fig. $1 a$ ), the three chains of fibrinogen $(\alpha, \beta, \gamma)$, and $\beta$-actin in less than a single rat or mouse liver cell. PF-4 could be detected in less than $100 \mathrm{pg}$ of megakaryocyte RNA. RT-PCR also detected mRNA transcripts for IgG in spleen (Fig. $1 b$ ); primers for the constant region of mouse IgG- $\kappa$ light chain $\left(\mathrm{C}_{\kappa}\right)$ were used because $90 \%$ of mouse and rat IgGs have $\kappa$ chains. However, in neither the enriched rat megakaryocyte preparations (85\%-90\% pure) (Fig. $2 a$ ) nor the pure mouse megakaryocyte colonies grown for seven days (Fig. $2 b$ ) could mRNA transcripts for fibrinogen $(\alpha, \beta, \gamma)$, albumin, or $\operatorname{IgG}\left(\mathrm{C}_{\kappa}\right)$ be detected. Transcripts for fibrinogen $(\gamma)$ also were not detected in immature megakaryocyte colonies grown for three or five days (data not shown). In contrast, mRNA transcripts for PF-4 (Fig. $2 a, b$ ) and $\beta$-actin (Fig. $2 \mathrm{a}, \mathrm{b}$ ) were easily seen in these samples. The identities of PCR fragments were validated by cutting with restriction enzymes (Fig. 3). Although megakaryocytes of $>85 \%$ purity did not contain detectable mRNA transcripts for fibrinogen, these transcripts were detected in whole bone marrow and in one preparation with 50\% megakaryocytes (Table II). IgG transcripts were detected in whole bone marrow but not in the pure megakaryocyte colonies. Albumin was not detected in any sample, even though $\leq 0.03$ transcripts per bone marrow megakaryocyte would have been detected.

Since the RT-PCR technique was sensitive enough to have detected less than one mRNA transcript per megakaryocyte, we conclude that megakaryocytes do not synthesize fibrinogen, albumin, or IgG. These data, taken together with previous observations $(3,9-12)$, indicate that megakaryocytes incorporate the fibrinogen, albumin, and IgG found in their $\alpha$-granules from plasma.

Our results with fibrinogen conflict with those of previous investigators (5-7), who reported that fibrinogen is synthesized by megakaryocytes in $50 \%-80 \%$ pure preparations; however, an earlier study failed to show fibrinogen synthesis in cultured megakaryocytes (31). The structure and function of platelet fibrinogen is also a much disputed subject. Although some investigators have suggested that platelet fibrinogen is different from plasma fibrinogen (32), many of these differences may be
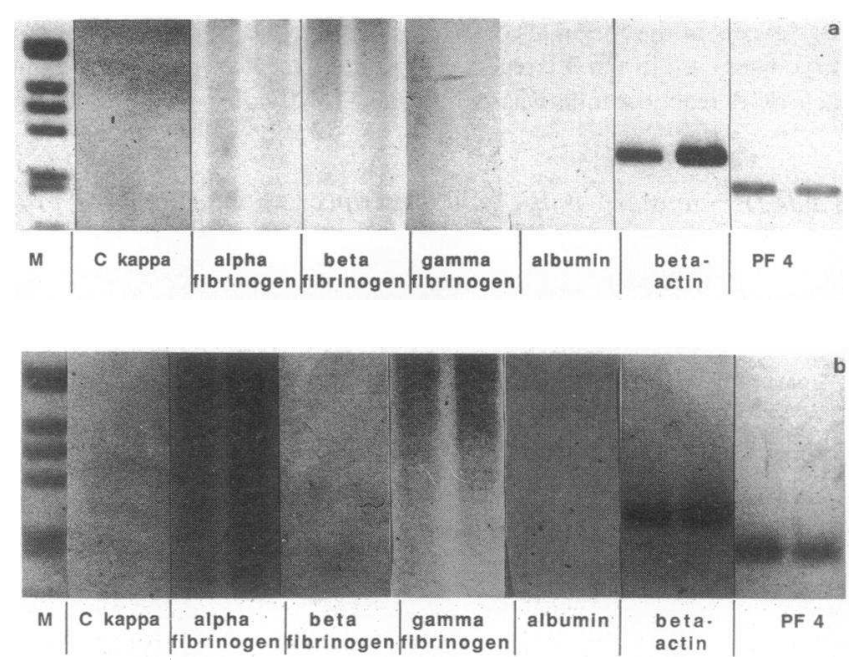

Figure 2. (a) RT-PCR of purified rat bone marrow megakaryocytes. $\beta$-actin and PF-4 are endogenous megakaryocyte proteins used as positive controls. Duplicate preparations from one of two or three experiments are shown for each primer pair. (b) RT-PCR of mouse megakaryocyte colonies grown in soft agar cultures for seven days. Duplicate preparations from one of three experiments are shown for each primer pair. $M$, the molecular weight markers as shown in Fig. $1 a$. 


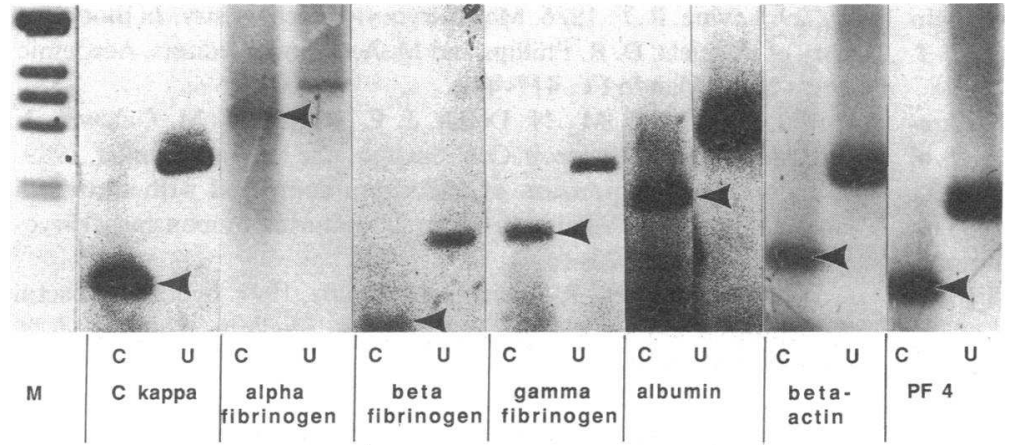

Figure 3. Restriction enzyme analysis of DNA fragments generated by RT-PCR (arrows). The amplified fragments $(100 \mu l)$ were ethanol-precipitated and then digested with the restriction enzymes indicated in Table I, according to the manufacturer's instructions (Bethesda Research Labs, Promega Biotech, Madison, WI, or New England Biolabs, Beverly, MA). Paired digested $(C)$ and undigested $(U)$ fragments were fractionated on $4 \%$ agarose gels and stained with ethidium bromide. $M$, the molecular weight markers as shown in Fig. $1 a$. explained by $\gamma$-chain heterogeneity and degradation during purification (33-36). Our data suggest that bone marrow cells other than megakaryocytes contain fibrinogen transcripts. In preliminary experiments we found that some macrophages and granulocyte-macrophage colonies contain fibrinogen-specific mRNA and/or immunohistochemically stainable fibrinogen (data not shown). Thus, previous results indicating that megakaryocytes synthesize fibrinogen could be due to contamination with mRNA from other cells, such as macrophages. In addition, it has been reported that megakaryocytes grown in vitro contain fibrinogen only if the culture medium contains fibrinogen (30). These observations are in accord with the present data showing that megakaryocytes cannot synthesize fibrinogen.

The uptake and incorporation of fibrinogen into granules by megakaryocytes and platelets is probably mediated by receptors. Assuming a normal human platelet volume of $9.6 \mathrm{fl}$ (37) and an $\alpha$-granule content of $\sim 8 \%$ of platelet volume (38), the $\alpha$-granule concentrations for fibrinogen (39), PF-4 (40), albumin (41), and IgG (41) are 91.3, 41.3, 31.6, and $6.5 \mathrm{fg} / \mathrm{fl}$, respectively; the plasma concentrations for these proteins are 3.0 , trace, 42.8 , and $11.3 \mathrm{fg} / \mathrm{ll}$, respectively. Thus, the ratios of $\alpha$-granule:plasma concentrations are $30.4,>10^{6}, 0.7$, and 0.6 , respectively. Note that the ratios of all three proteins not synthesized by megakaryocytes (fibrinogen, albumin, and IgG) are much lower than that of the endogenously synthesized PF-4. Because the concentration of fibrinogen, but not of albumin or IgG, is higher in $\alpha$-granules than in plasma, the uptake of fibrinogen may be more efficient. Megakaryocytes and platelets possess the integrin glycoprotein (GP) IIb-IIIa complex, a well-characterized fibrinogen receptor (42). It is tempting to hypothesize that this receptor mediates the uptake of fibrinogen by megakaryocytes and platelets, because patients with Glanzmann's thrombasthenia, who have a congenital platelet GPIIb-IIIa deficiency, have an unexplained parallel deficiency of platelet fibrinogen $(43,44)$. In contrast, $\alpha$-granule albumin and IgG are probably acquired by fluid-phase endocytosis (45). This hypothesis is supported by the observed correlation between the concentrations of albumin and IgG in platelets and plasma over a wide range of normal and abnormal values (41).

In summary, megakaryocytes and platelets appear to have two mechanisms for acquiring proteins for their major secretory organelle, the $\alpha$-granules. Some proteins, such as PF-4, are endogenously synthesized, whereas others are endocytosed from plasma. It may be possible to use the endocytic pathway to insert pharmacological agents into platelet $\alpha$-granules, perhaps by attaching a receptor recognition sequence to the drug.
This pathway could serve as a new way to deliver drugs to sites of platelet activation, such as areas of vascular injury and thrombi.

\section{Acknowledgments}

Dr. Handagama is a fellow of the American Heart Association, San Francisco and San Mateo chapter, California affiliate. This research was supported by research grants HL-31610 and HL-31035 from the National Heart, Lung, and Blood Institute of the National Institutes of Health; the Office of Health and Environmental Research, U. S. Department of Energy (contract no. DE-ACO3-76-SF01012); a National Research Service Award (ES-07106); and the Veterans Administration.

\section{References}

1. Palade, G. 1975. Intracellular aspects of the process of protein synthesis. Science (Wash. DC). 189:347-358.

2. Lingappa, V. R. 1989. Intracellular traffic of newly synthesized proteins. J. Clin. Invest. 83:739-751.

3. Handagama, P. J., M. A. Shuman, and D. F. Bainton. 1989. Incorporation of intravenously injected albumin, immunoglobulin $G$ and fibrinogen in guinea pig megakaryocyte granules. J. Clin. Invest. 84:73-82.

4. Beckstead, J. H., P. E. Stenberg, R. P. McEver, M. A. Shuman, and D. F. Bainton. 1986. Immunohistochemical localization of membrane and $\alpha$-granule proteins in human megakaryocytes. Application to plastic-embedded bone-marrow specimen. Blood. 67:285-293.

5. Leven, R. M., P. K. Schick, and A. Z. Budzynski. 1985. Fibrinogen biosynthesis in isolated guinea pig megakaryocytes. Blood. 65:501-504.

6. Belloc, F., P. Hourdille, P. Fialon, M. R. Boisseau, and J. Soria. 1985. Fibrinogen synthesis by megakaryocyte rich human marrow cell concentrate. Thromb. Res. 38:341-351.

7. Uzan, G., G. Courtois, Z. Stanckovic, G. R. Crabtree, and G. Marguerie. 1986. Expression of the fibrinogen genes in rat megakaryocytes. Biochem. Biophys. Res. Commun. 140:543-549.

8. George, J. N., S. Saucerman, S. P. Levine, L. K. Knieriem, and D. F. Bainton. 1985. Immunoglobulin $G$ is a platelet alpha granule-secreted protein. J. Clin. Invest. 76:2020-2025.

9. Handagama, P. J., J. N. George, M. A. Shuman, R. P. McEver, and D. F. Bainton. 1987. Incorporation of a circulating protein into megakaryocyte and platelet granules. Proc. Natl. Acad. Sci. USA. 84:861-865.

10. Handagama, P. J., and D. F. Bainton. 1989. Incorporation of a circulating protein in alpha granules of megakaryocytes. Blood Cells (Berl.) 15:59-72.

11. Harrison, P., B. Wilbourn, N. Debili, W. Vainchenker, J. Breton-Gorius, A. S. Lawrie, J. M. Masse, G. F. Savidge, and E. M. Cramer. 1989. Uptake of plasma fibrinogen into the alpha granules of human megakaryocytes and platelets. J. Clin. Invest. 84:1320-1324. 
12. Harrison, P., G. F. Savidge, and E. M. Cramer. 1990. The origin and physiological relevance of $\alpha$-granule adhesive proteins. $B r . J$. Haematol. 74:125-130.

13. Handagama, P., R. Shuman, M. A. Shuman, and D. F. Bainton. 1988. In vivo defibrination results in markedly decreased levels of fibrinogen in rat megakaryocytes and platelets in rats. Blood. 72:323a. (Abstr.)

14. Evatt, B. L., and J. Levin. 1969. Measurement of thrombopoiesis in rabbits using ${ }^{75}$ selenomethionine. J. Clin. Invest. 48:16151626.

15. Rabellino, E. M., R. L. Nachman, N. Williams, R. J. Winchester, and G. D. Ross. 1979. Human megakaryocytes. I. Characterization of the membrane and cytoplasmic components of isolated marrow megakaryocytes. J. Exp. Med. 149:1273-1287.

16. Rappolee, D. A., D. Mark, M. J. Banda, and Z. Werb. 1988. Wound macrophages express TGF- $\alpha$ and other growth factors in vivo: Analysis by mRNA phenotyping. Science (Wash. DC). 241:708-712.

17. Rappolee, D. A., A. Wang, D. Mark, and Z. Werb. 1989. Novel method for studying mRNA phenotypes in single or small numbers of cells. J. Cell. Biochem. 39:1-11.

18. Levin, J., F. C. Levin, D. G. Penington, and D. Metcalf. 1981. Measurement of ploidy distribution in megakaryocyte colonies obtained from culture: with studies of the effects of thrombocytopenia. Blood. 57:287-297.

19. Stenberg, P. E., J. H. Beckstead, R. P. McEver, and J. Levin. 1986. Immunohistochemical localization of membrane and $\alpha$-granule proteins in plastic-embedded mouse bone marrow megakaryocytes and murine megakaryocyte colonies. Blood. 68:696-702.

20. Stenberg, P. E., and J. Levin. 1987. Ultrastructural analysis of murine megakaryocyte maturation in vitro. Comparison of big-cell and heterogeneous megakaryocyte colonies. Blood. 70:1509-1518.

21. Sargent, T. D., M. Yang, and J. Bonner. 1981. Nucleotide sequence of cloned rat serum albumin messenger RNA. Proc. Natl. Acad. Sci. USA. 70:243-246.

22. Crabtree, G. R., C. M. Comeau, D. M. Fowlkes, A. J. Fornace, Jr., J. D. Malley, and J. A. Kant. 1985. Evolution and structure of the fibrinogen genes: Random insertion of introns or selective loss? J. Mol. Biol. 185:1-19.

23. Kant, J. A., S. T. Lord, and G. R. Crabtree. 1983. Partial mRNA sequences for human $\mathrm{A} \alpha \mathrm{B} \beta$ and $\gamma$ fibrinogen chains: Evolutionary and functional implications. Proc. Natl. Acad. Sci. USA. 80:3953-3957.

24. Doi, T., S. M. Greenberg, and R. D. Rosenberg. 1987. Structure of the rat platelet factor 4 gene: A marker for megakaryocyte differentiation. Mol. Cell. Biol. 7:898-904.

25. Alonso, S., A. Minty, Y. Bourlet, and M. Buckingham. 1986. Comparison of three actin-coding sequences in the mouse; evolutionary relationships between the actin genes of warm-blooded vertebrates. J. Mol. Evol. 23:11-22.

26. Max, E. E., J. V. Maizel, Jr., and P. Leder. 1981. The nucleotide sequence of a 5.5-kilobase DNA segment containing the mouse $\kappa$ immunoglobulin $\mathrm{J}$ and $\mathrm{C}$ region genes. J. Biol. Chem. 256:5116-5120.

27. Krebs, H. A., N. W. Cornell, P. Lund, and R. Hems. 1974. Isolated liver cells as experimental material. In Regulation of Hepatic Metabolism. F. Lundquist and N. Tygstrup, editors. Academic Press, New York. 726-750.

28. Crabtree, G. R., and J. A. Kant. 1981. Molecular cloning of cDNA for the $\alpha, \beta$ and $\gamma$ chains of rat fibrinogen. J. Biol. Chem. 256:9718-9723.
29. Levine, R. F. 1986. Megakaryocyte biochemistry. In Biochemistry of Platelets. D. R. Phillips and M. A. Shuman, editors. Academic Press Inc., Orlando FL. 417-442.

30. Cramer, E. M., N. Debili, J. F. Martin, A. M. Galdwin, J. Breton-Gorius, P. Harrison, G. F. Savidge, and W. Vainchenker. 1989. Uncoordinated expression of fibrinogen compared with thrombospondin and von Willebrand factor in maturing human megakaryocytes. Blood. 73:1123-1129.

31. Nachman, R., R. Levine, and E. Jaffe. 1978. Synthesis of actin by cultured guinea pig megakaryocytes. Biochim. Biophys. Acta. 543:91-105.

32. James, H. L., P. Ganguly, and C. W. Jackson. 1977. Characterization and origin of fibrinogen in blood platelets. A review with recent data. Throm. Haemostasis. 38:939-954.

33. Wolfenstein-Todel, C., and M. W. Mosesson. 1980. Human plasma fibrinogen heterogeneity: Evidence for an extended carboxyterminal sequence of a normal $\gamma$ chain variant $\left(\gamma^{\prime}\right)$. Proc. Natl. Acad. Sci. USA. 77:5069-5073.

34. Haidaris, P. J., C. W. Francis, L. A. Sporn, D. S. Arvan, F. A. Collichio, and V. J. Marder. 1989. Megakaryocyte and hepatocyte origins of human fibrinogen biosynthesis exhibit hepatocyte-specific expression of $\gamma$ chain-variant polypeptides. Blood. 74:743-750.

35. Doolittle, R. F., T, Takagi, and B. A. Cottrell. 1974. Platelet and plasma fibrinogen are identical gene products. Science (Wash. DC). $185: 368-370$.

36. Kuniki, T. J., P. J. Newman, D. L. Amrani, and M. W. Mosesson. 1985. Human platelet fibrinogen: Purification and hemostatic properties. Blood. $66: 808-815$.

37. Files, C., T. W. Malpass, E. K. Yee, J. L. Ritchie, and L. A. Harker. 1981. Studies of human platelet alpha granule release in vivo. Blood. 58:607-618.

38. Mosher, D. F., D. M. Presciotta, D. M. Loftus, and R. M Albrecht. 1985. Secreted alpha granule proteins. In The Race for Receptors: Platelet Membrane Glycoproteins. J. N. George, A. T. Nurden, and D. R. Phillips, editors. Plenum Publishing Corp., New York. 171-191.

39. Gerrard, J. M., D. R. Phillips, G. H. R. Rao, E. F. Plow, D. A. Walz, R. Ross, L. A. Harker, and J. G. White. 1980. Biochemical studies of two patients with the gray platelet syndrome. Selective deficiency of platelet alpha granules. J. Clin. Invest. 66:102-109.

40. Levine, S. P. 1986. Secreted platelet proteins as markers for pathological disorders. In Biochemistry of Platelets. D. R. Phillips and M. A. Shuman, editors. Academic Press Inc., Orlando, FL. 377-415.

41. George, J. N., and S. Saucerman. 1988. Platelet IgG, IgA, IgM, and albumin. Correlation of platelet and plasma concentrations in normal subjects and in patients with ITP or dysproteinemia. Blood. 72:362-365.

42. Phillips, D. R., I. F. Charo, L. V. Parise, and L. A. Fitzgerald. 1988. The platelet membrane glycoprotein IIb-IIIa complex. Blood. $71: 831-843$

43. Nurden, A. T. 1989. Congenital abnormalities of platelet membrane glycoproteins. In Platelet Immunobiology: Molecular and Clinical Aspects. T. J. Kunicki and J. N. George, editors. J. B. Lippincott Co., Philadelphia. 63-96.

44. George, J. N., A. T. Nurden, and D. R. Phillips. 1984. Molecular defects in interactions of platelets with the vessel wall. $N$. Engl. J. Med. 311:1084-1098.

45. Steinman, R. M., I. S. Mellman, W. A. Muller, and Z. A. Cohn 1983. Endocytosis and recycling of plasma membrane. J. Cell Biol. 92:1-27 